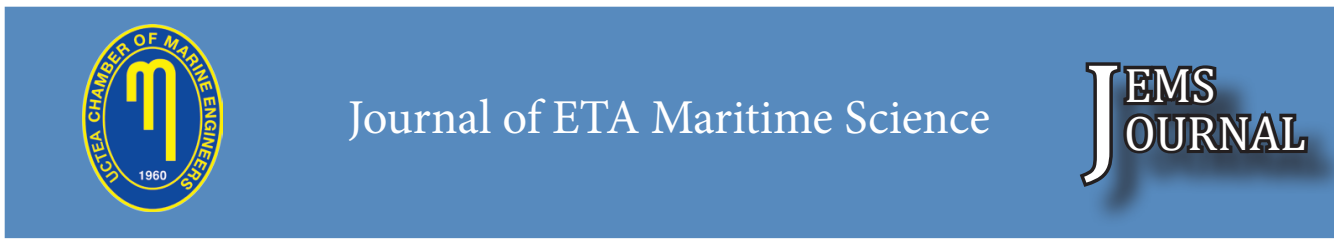

Corresponding Author: Aysu GÖÇER

\title{
Revealing Marketing Criteria of Customs Services: A Dyadic Approach
}

\section{İlkyaz İLDEŞ, Aysu GÖÇER}

İzmir University of Economics, Department of Logistics Management, Turkey ilkyaz-ildes@hotmail.com; ORCID ID: https://orcid.org/0000-0003-2862-992X aysu.gocer@ieu.edu.tr; ORCID ID: https://orcid.org/0000-0001-7343-7703

\begin{abstract}
The increasing importance of marketing services has led services industries to pursue ways of providing better services and improve customer satisfaction in a competitive marketplace. Knowing what can be promoted and what customers consider in choosing the service provider are important factors in a strategic marketing plan. Recognizing core competences with customer expectations and perceptions is undoubtedly the best tool for success. While services marketing has been studied for many services industries, logistics, particularly customs services, is rarely addressed. Exploiting services quality and perception scales, this qualitative study applied content analysis to semi-structured interviews to explore the marketing criteria of customs service providers from a dyadic perspective within businessto-business (B2B) services. Marketing criteria for customs services were categorized as company, personnel, and service-oriented. Three genuine dimensions were created in accordance with their relevance to the service provider company, employees working in the service provider company and the service itself. The results reveal that customs services marketing criteria taken into consideration by customers for service provider choice can be different when compared to other services within a B2B environment. This study contributes to services marketing regarding customs services by comparing the factors of logistics services quality and perception literature.
\end{abstract}

Keywords: Customs Services, B2B Marketing, Dyadic Approach.

\section{Gümrük Hizmetlerinde Pazarlama Kriterlerinin Ortaya Çıkarılması: İki Taraflı Bir Yaklaşım}

$\ddot{O} z$

Hizmet pazarlamasına verilen önemin giderek artması, hizmet sektörünü rekabetçi pazarda daha iyi hizmet sağlama ve müșteri memnuniyetini iyileștirme çabasına sokmuştur. Stratejik bir pazarlama planını benimsemek için güçlü şekilde pazarlanabilecek yetkinliklerin ve müşterilerin hizmet sağlayıcı seçerken temel olarak göz önünde bulundurduğu faktörlerin farkında olmaları oldukça önemlidir. Müșteri beklentilerinin ve algısının yanı sıra temel yetkinlikleri bilmek, şüphesiz ki başarıya giden yoldaki en iyi araçtır. Hizmet pazarlaması birçok hizmet sektörü açısından çalışmalara kapsamlı bir şekilde konu edilmiş olmasına rağmen diş ticaret șirketleri için yadsınamaz öneme sahip gümrük hizmetleri neredeyse hiç çalışılmamıştır. Hizmet kalitesi ve algısı ölçeklerinden yararlanılan bu çalışmada pazarlama kriterlerini çift yönlü olarak ortaya koymak üzere hizmet sağlayıcılar ve müşteri şirketlerle yürütülen yarı yapılandırılmış görüşmelere içerik analizi uygulanmıştır. Gümrük hizmetleri 
pazarlamacıları için şirket, personel ve hizmet odaklı pazarlama boyutları geliştirilmiştir. Bu çalışma, lojistik hizmet kalitesi ve algısı literatüründeki benzer faktörlerle karşılaştırma yaparak hizmet pazarlamasına katkıda bulunmaktadır. Hizmet sağlayıcı şirket, hizmet sağlayıcı şirket personeli ve hizmetin kendisiyle ilgili özgün nitelikte üç boyut oluşturulmuştur. Çalıșmanın sonucunda, müşterilerin hizmet sağlayıcı seçimi yaparken göz önünde bulundurduğu gümrük hizmetleri pazarlama kriterlerinin işletmeden işletmeye konseptinde diğer hizmetlere klyasla farklılık gösterebildiği ortaya konulmuştur.

Anahtar Kelimeler: Gümrük Hizmetleri, Hizmet Pazarlamasl, İşletmeden İşletmeye Hizmet Sektörü, Pazarlama Kriterleri

\section{Introduction}

In a B2B environment, customs services are widely used by companies dealing with import and export. For a foreign trade company, customs services are essential for managing the complex liabilities specific to each country in terms of international commerce. Customs brokers mainly carry out customs clearance transactions, arrange freight transport and buy space in ships, although some have evolved into forwarders, called Third or Fourth Party Logistics (3PL or 4PL) companies. As the vital role of brokers has expanded further, researchers have focused on customs tariffs and the effects of the relationships among countries and nations on the customs environment [1].

Foreign trade activities cannot be conducted without comprehensive knowledge of the customs tariffs and regulations specific to each country. Excelling at customs regulations, therefore, requires a substantial accumulation of knowledge and experience, which seems impracticable for foreign trade companies as they must deal with several activities, such as production, procurement, sales, supply chain management, and customer relations. Thus, customs services are indisputably important to most companies [2]. Since these services cannot be performed without certain requirements and certificates under relevant regulations, the importance of companies providing customs services cannot be ignored. This makes the choice of customs service providers a strategic decision for trading companies.

At the same time, factors affecting customers in choosing service providers should also be prioritized by customs service providers since marketing includes both understanding what capabilities can be promoted by service providers and how these capabilities are perceived by customer companies when being marketed in a B2B environment [2]. However, although there have been many studies on customs services regarding their international, economic, political and regulatory effects [3], the marketing of these services has not been addressed in terms of engaging both parties as a service provider and service receiver.

This study aims to discover what customers value in choosing a customs services partner, and how customs service providers implement marketing strategies to attract new customers or retain existing customers. This dyadic research perspective also explores whether there is a gap between the marketing strategies applied by customs services and their perceived importance by customer companies. In this sense, the expectations and perceptions of customers receiving customs services are analyzed comparatively by exploring the differences between them. Drawing on widely recognized service quality measurement models, such as Service Quality (SERVQUAL) and Logistics Service Quality (LSQ) from a service-dominant (S-D) perspective, differences or additional factors in providing and choosing customs services are detected. These two scales provide insights about customer expectations and perceptions that are vital for marketing planning since they determine how services are introduced to customers [4].

This study highlights the importance of customs services and customs broker agencies in the economy for both companies 
receiving service and government authorities [5] and suggests the need to develop a clearer articulation of measures for providing service quality, perceived value, benefits, customer satisfaction and ultimately behavioral intentions regarding certain services marketing. This study therefore effectively fills the gap existing in the services marketing literature regarding customs services marketing efforts and ultimately contributes to the services marketing literature by exclusively focusing on customs services marketing criteria from a dyadic perspective as well as giving insights to marketers for promoting better customs services and improving customer satisfaction.

This study consists of five sections giving insight into the introduction to the study, literature review on services marketing, the methodology of the study, analysis of findings, and conclusion.

\section{Literature Review}

\subsection{Service-Dominant Logic}

The services literature concerns service systems constituted by "value-coproduction configuration of people, technology, other internal and external service systems, and shared information (such as language, processes, metrics, prices, policies, and laws)" [6]. Wladawsky-Berger [7] notes that service systems correspond to marketfacing complex systems and therefore involve economic exchange. Accordingly, the services discipline is necessarily based on market exchange processes involving people's interaction, innovation, learning, and technological evolution.

S-D logic is triggered by the lack of integrated, elementary knowledge to assist service systems in the process of service innovation and provision for achieving more anticipating results since companies progress towards an orientation towards service instead of manufacturing [8].

S-D logic includes a re-evaluation of the meaning and performance of resources, which is considered useful for this study in analyzing customs services marketing strategies in terms of discussing "value creation" and "intangible resources" [9]. $\mathrm{S}-\mathrm{D}$ logic is considered to provide the foundation for the marketing criteria discussed throughout this study regarding how customs brokerage companies better attract customers and create value mutually. By covering the whole process in service systems, S-D logic helps this study to comprehensively assess existing processes among service systems and ultimately suggest better solutions to create value and develop the process itself [10]. By taking into consideration and highlighting operant resources identified from interviews carried out with both service providers and beneficiaries, i.e. companies receiving services, this study proposes new ways of marketing services as a value creation process for customs services providers.

\subsection{Quality and Perception in Services}

Service marketing and service management paradigms can only be developed effectively by acknowledging what customers in the marketplace expect and what they evaluate in the customer relationship with service providers. To create a realistic, effective model for marketing services, first a clear understanding is required of the term "service quality", frequently mentioned by many academicians and practitioners in the services field [11].

Since services are intangible performance and/or processes instead of tangible goods, an unvarying quality standard can hardly be set for a services environment so it is harder for customers to evaluate service quality than goods quality. Service quality is basically measuring the service delivery provided by the service provider with the intention of matching customer expectations [12].

Service quality originates from the 
contrast between what customers feel a seller or provider should ideally offer, in other words, the expectations of customers, with the actual performance. This expectationperformance gap approach was broadly discussed and suggested by Parasuraman et al. [12], who described service quality as the level and direction of the discrepancy between customers' expectations and actual service perceptions.

There have been many studies on the attributes that customers adopt as criteria to assess service quality. Three distinct attributes were suggested regarding the service delivery process: material, facilities and personnel [13]. Grönroos [14] introduced two types of service quality: technical quality and functional quality. Subsequent studies extended the scope of physical distribution as an element of logistics, which led to the formation of the logistics service quality scale (LSQ) by Mentzer et al. [15], which consists of nine key components. Lehtinen and Lethinen [16] proposed a three-way perspective of physical, corporate and interactive quality. However, as Parasuraman et al. [12] claim, customers assess the service they are receiving in terms of the associated process as well as the service delivery as an outcome. Emphasizing the significance of process attributes in customers' service quality evaluation, they suggested ten evaluative dimensions before conducting further empirical studies in various industries to establish and improve their SERVQUAL model. The resulting SERVQUAL scale is a multiple-item tool for measuring service quality across five common dimensions originating from their ten evaluative dimensions; (i) reliability - the ability to perform the guaranteed service accurately; (ii) responsiveness - the willingness to help customers and supply immediate service; (iii) assurance - knowledge and courtesy of personnel and their ability to encourage trust and confidence; (iv) empathy - the care, customized attention provided to customers; and (v) tangibles - the appearance of physical facilities, equipment, staff and communication means. This model describes the linkages and interaction among the service provider's key activities that aim to deliver quality service. Links are considered as gaps or discrepancies; in other words, they symbolize critical barriers to achieving service quality satisfaction. Despite being 20 years old, SERVQUAL continues to be useful for service quality studies when different service quality assessment methods are considered. However, each service setting may have its own relevant dimensions to reflect the very specific nature and dynamics of each service setting. Considering this and to discuss service quality from a more customized perspective for marketing purposes, this study recognizes logistics services quality as part of the supply chain.

\subsection{Business-to-business Marketing Services}

Different requirements occur due to the nature of B2B marketing as compared to other models of marketing. Specifically, since the B2B model is applied to a professional environment, marketing to business requires certain professional key aspects to be considered, particularly for service-oriented organizations [17].

One of the most critical points in $\mathrm{B} 2 \mathrm{~B}$ marketing in services is personnel competence and skills. Due to the nature of the services industry and the B2B model, the value of customer relations, customer loyalty, and management of customer relations has increased. Therefore, it is beneficial for such companies to gain insights about customer service expectations and perceptions, follow industrial developments in terms of a costbenefit analysis and achieve continuous powerful communication for also B2B models. 


\section{Methodology}

\subsection{Methodological Framework}

Qualitative research methodologies are extensively associated with the aspects of service as well as the nature of service products, given that service is a process and a performance where service delivery takes place by means of human interaction. Qualitative research is appropriate when analyzing services marketing, as Gilmore and Carson [18] note. Since this study aims to develop marketing criteria for customs services by considering the reviews of people engaging in customs services, whether providing or receiving, it adopts qualitative research methods from various academic disciplines, though predominantly in marketing research [19].

The fit between qualitative research and this study's goal to analyze the dynamic reviews of people engaging the service process based on their experience means that this study was carried out with a qualitative approach, utilizing semistructured interviews to contribute to the services marketing literature in customs services.

\subsection{Sampling and Data Collection}

To discover the marketing criteria adopted by customs services providers and taken into consideration by customer companies while choosing the service provider, a thorough literature review was conducted on service provider selection, B2B marketing, service quality scales, and service perceptions. In addition to supporting relevant research mentioned earlier related to this study's main goals, no study has yet been done on marketing criteria from a dyadic perspective for customs services in a developing economy like Turkey, leaving a gap in the literature. Thus, this study aims to discover the marketing criteria for customs services by sampling Turkey through a two-way approach.
This study used semi-structured interviews as the data collection method by asking previously prepared questions to the sample group of companies providing customs services and companies receiving customs services [20].

Semi-structured interviews are defined as a verbal interchange where the interviewer tries to elicit information from the interviewee. Although questions are generally prepared by the interviewer before the interview, semistructured interviews also unfold through a conversational method that gives participants the opportunity to discover the issues they consider significant [21].

Semi-structured interviews were appropriate for collecting data in this study in order to elicit the participants' detailed narratives and stories that reflect real-life phenomena within the customs services industry by generating an intimate and personal environment for the participants. Questions were prepared beforehand to avoid loss of data and time spent with the participants.

The semi-structured interview questions were prepared from a checklist identifying areas to be clarified and issues to be resolved. Marketing managers or certified customs clearance brokers from service provider companies were interviewed as shown in Table 1. In the table below, companies' activity of fields as industry, establishment years, operation offices, and their scale according to the number of branches across the world are given to provide insight on the sample of the study. Employees from the foreign trade department or senior management of companies receiving customs services were interviewed to better reflect the reallife relationships and conditions regarding the customs process. Participants were asked to answer ten open-ended questions in an intimate and quiet environment within their own premises to retain 
Table 1. Characteristics of Companies

\begin{tabular}{|c|c|c|c|c|}
\hline Codes & Industry & Establishment & Operation Offices & Scale \\
\hline P1 & $\begin{array}{l}\text { Customs clearance, logistics, storage and order } \\
\text { management }\end{array}$ & 1982 & $\begin{array}{l}18 \text { in Turkey, } 61 \\
\text { overseas }\end{array}$ & Large \\
\hline P2 & Customs clearance and consultancy & 2006 & 1 in Izmir & Medium \\
\hline P3 & $\begin{array}{l}\text { Customs clearance, logistics, consultancy and } \\
\text { export-import transactions }\end{array}$ & 2013 & 1 in Izmir & Medium \\
\hline $\mathrm{P} 4$ & $\begin{array}{l}\text { Customs clearance, logistics, insurance and } \\
\text { training }\end{array}$ & 2001 & 19 in Turkey & Large \\
\hline P5 & $\begin{array}{l}\text { Customs clearance, logistics, consultancy, } \\
\text { warehouse, insurance }\end{array}$ & 2000 & 8 in Turkey & Medium \\
\hline P6 & Customs clearance and consultancy & 1992 & 1 in Izmir & Small \\
\hline P7 & Customs clearance and consultancy & 2016 & 1 in Izmir & Small \\
\hline P8 & Customs clearance and consultancy & 2016 & 1 in Izmir & Small \\
\hline P9 & $\begin{array}{l}\text { Customs clearance, logistics, insurance, storage } \\
\text { management, and training }\end{array}$ & 1978 & 16 in Turkey & Large \\
\hline P10 & $\begin{array}{l}\text { Customs clearance, logistics, insurance, } \\
\text { translation, and training }\end{array}$ & 1981 & 46 in Turkey & Large \\
\hline $\mathrm{C} 1$ & Textiles & 2012 & 1 in Turkey & Small \\
\hline $\mathrm{C} 2$ & Fibres & 1997 & 3 in Turkey & Large \\
\hline $\mathrm{C} 3$ & Food & 2005 & 1 in Turkey & Small \\
\hline $\mathrm{C} 4$ & Granite consumer goods & 1960 & 2 in Turkey & Medium \\
\hline $\mathrm{C} 5$ & Energy & 1984 & $\begin{array}{l}1 \text { in Izmir, various } \\
\text { overseas }\end{array}$ & Large \\
\hline C6 & Confectionary & 1940 & $\begin{array}{l}2 \text { in Turkey, various } \\
\text { overseas }\end{array}$ & Large \\
\hline C7 & Metal casting & 2011 & 1 in Izmir & Medium \\
\hline $\mathrm{C} 8$ & Textiles & 1990 & 1 in Izmir & Large \\
\hline $\mathrm{C} 9$ & Industrial kitchens & 1978 & 1 in Izmir & Small \\
\hline C10 & Paper & 2000 & 3 in Turkey & Medium \\
\hline
\end{tabular}

mutual professionality and confidence. The interviews, which took twenty-five minutes to an hour, were all recorded and transcribed for further analysis.

Ten companies providing customs services in the B2B model and ten companies receiving customs services were chosen for the semi-structured interview aiming to determine marketing criteria.

The interview data were then subjected to content analysis in which the recordings were studied carefully to extract first-order codes for marketing criteria that were supported by quotations.

\section{Analysis and Findings}

The content analysis applied to the customer and provider interviews revealed fifty first-order codes, that is, the marketing factors. These first-order codes were thoroughly analyzed and re-matched with quotations to ensure their validity. They were then cross-analyzed with the literature on service quality and perceptions since marketing criteria are concerned with both the providers' offerings and the customers' choice patterns. SERVQUAL and LSQ factors provided insights to group associated firstorder factors into second-order codes. 
These two scales, which address service expectations and perceptions helped to code first-order factors to identify overall marketing criteria. In contrast to the literature, however, the first-order codes discovered in this study reflect the similarities and differences between the perspectives of service providers and customer companies. Finally, these ten second-order codes with their associated first-order codes were latently categorized into three interconnected, generic dimensions for customs services marketing criteria.

\subsection{Company-Oriented Dimension}

The "Company-Oriented" dimension highlights the service provider company's organizational capabilities regarding the B2B marketing model and service customers' perceptions. Seventeen firstorder codes were categorized under four second-order codes, namely geographical accessibility, information management, power, and recognition, which highlight customs services providers' corporate capabilities to attract customers through their marketing efforts considering the choice criteria of customs services customers.

This dimension's first second-order code, "Geographical accessibility", addresses the existence and/or availability of the provider company's facility or services in various locations through partners or own branches for ease of customs processing. According to the quotations, a service provider is more preferred if it can ensure its services at any location. For customers, it is important to access the services they need at any location by contacting only one service provider. Moreover, especially for customs services, closeness to customs ports was quite beneficial for both parties.

"Since I do not own any ship, I can provide service to my customers by contacting certain lines... (P1)"
"We are working with 2 different customs brokers due to geographical deficiency...(C6)"

The next second-order code, "Information management", refers to communication and technological adaptations for real-time information exchange. Due to customs' complex and ever-changing legal nature, information sharing was quoted as playing a vital role, especially for the accuracy of transactions.

"As more communication channels are involved, attracting customers is becoming easier...(P4)"

"For example, there is a software that the customs brokerage firm is connected to our system...(C4)"

The dimension's third second-order code, "Power", emphasizes the intangible strengths the service provider possesses in knowledge, law and the industry, which are critical to facilitate customs processing accurately.

"Because the customs broker is the person who knows every detail about the customer company and carries out procedures on behalf of its customers... (P1)"

"There can be some problems in customs, but they use their legal power and fix the problems... (C2)"

"We are capable of carrying out transactions in all customs bureaus in İzmir and in all affiliated customs offices... (P3)"

The final company-oriented secondorder code, "Recognition", concerns the promotional aspects of the provider company, such as the availability of a marketing department to arrange promotional efforts, a brand image with intangible standing within the industry, the provider's certification, corporate structure within its facility, customer references contributing to a word-of-mouth strategy, internet advertising to attract a wider range of customers, presentational marketing materials, the relationship network within 
the customs environment, respect gained due to operational and organizational achievements, and visits paid to customers for marketing purposes and to demonstrate the company's dedication to customers by checking their satisfaction face-to-face. According to the quotations, the recognition gained by these factors ensures the service provider's initial credibility for customers, which is extremely valuable for attracting customers directly.

"The marketing department constitutes the core of this company...(P5)"

"The more they get known, the more they have visibility in the industry...(C9)"

"The companyasks for certain documents to confirm our trustworthiness...(P1)"

"We expect our customs broker to ... work on improvements to build up a corporate identity...(C8)"

"Because customer firms know each other, they give recommendations to one another for provider firms related to transactions...(P8)"

"There is, yes, they send their e-mail addresses. I mean they advertise themselves...(C3)"

"According to the service demanded from us, I definitely bring an introduction booklet with me for the customer...(P1)"

"I think the best marketing strategies are customer reference and their network... (C6)"

"My customer firms respect me and the quality of my firm's services, so we have a good relationship...(P4)"

"We expect them to come to our company for a meeting together with their experts in sales and marketing...(C10)"

\subsection{Personnel-Oriented Dimension}

The "Personnel-Oriented" dimension represents various behavioral aspects and capabilities of employees working in customs services provider companies. This dimension includes three second-order codes - the attitude of customs personnel, the competence of customs personnel and customized attention - and nineteen firstorder codes. The quotations indicate that these three codes are critical from the perspective of both the service providers and customer companies regarding the marketing of customs services.

"Attitude of customs personnel" refers to the employees' stance when dealing with customer companies' transactions. It includes whether customs personnel are professional, frank, caring, confident, solution-oriented, open for improvement, trustworthy, innovative and ethical since services are perceived to be rendered by the personnel rather than provided by the company as a whole. This dimension highlights the fact that the personnel who deal with the customer and provide services determine service quality and perceptions, whether positively or negatively. Staff attitudes are quoted as very influential since they are the enablers of the requested services. Their manner while rendering services have either a pleasing or negative effect on customers. In the latter case, customers are likely to cease the partnership because they place such importance on the trust built with personnel, as well as with the company as a whole.

"In all our jobs, we are very selfless and delicate...(P3)"

"When we first visit a company, the important thing is frankness comes from personnel; so the attitude of the personnel is very important...(P4)"

"The personnel should be properly dressed, presentable and well-behaved... (C5)"

"We are sure of ourselves... (P10)"

"They should convert negative situations into a solution; they should adopt solutionoriented behavior...(C5)"

"Trust is the key point here and it is understood by the personnel's approach... (C5)" 
"Employees ... could be more innovative...(C6)"

"Because I need to develop myself, I do my own marketing activities...(P1)"

The next second-order code, "Competence of customs personnel", also contributes to the first idea in terms of the expertise, know-how and up-to-date knowledge the personnel possesses along with their training levels. It was quoted that the competence of customs personnel can make a difference in transactions besides highlighting the knowledge/experience power they have as a part of marketing activities.

"Personnel expertise also brings the quality of service together...(P4)"

"The ones who have deep knowledge make your transactions easier...(C7)"

"We send our customer representative for training or we arrange training in the customs broker company...(P5)"

"Customs brokers should have up-todate information, up-to-date regulation agenda, customs tariff codes, etc...(C5)"

The third second-order code, "Customized attention", concerns the level and method of the relationship built between personnel and customers. It was recognized by the special bond and the availability of customer representatives, preliminary research carried out on a customer company's profile, satisfaction feedback from existing customers and extra support given to customers.

"We are employing specially selected teams for our VIP customers...(P10)"

"We want the customs broker to care for our business personally, so to interpret regulation changes beforehand and inform us regarding both the positive and negative effects of such change...(C6)"

"After market research, we evaluate potential customer companies and call them accordingly...(P5)"

"We visit the firms we work with monthly to check their satisfaction...(P8)"
"Because of their customized attention, it does not change for years; they become like your partner...(C2)"

"We are supporting our customers at all points as we are a solution partner... (P10)"

\subsection{Service-Oriented Dimension}

The last dimension is named "ServiceOriented" as it refers to service-related aspects in marketing customs services. This dimension consisted of three second-order codes along with fourteen first-order codes. The three second-order codes covered were quality of customs process, services variety and value perception on customs services. These aspects were quoted as determining both service perceptions and service quality in both the marketing phase and the actual performance of service provision.

The first second-order code, "Quality of customs process", highlighted the accuracy, speed and traceability of customs processes since customs related transactions are subject to legal regulations and tariffs. The quality of customs processing constituted the foundation of the partnership between the service provider and customer company, similarly to what has been seen with the LSQ and SERVQUAL scales within the literature throughout the history of the services quality principle. Especially in customs services, accuracy and speed are essential to avoid sanctions for incorrect or delayed transactions. Thus, service providers are expected to act quickly and in accordance with regulations.

"We need to hand in the reports, documents, etc. requested by the customer on time and as requested without a mistake...(P9)"

"If there is a delay on due time, this is not something that can be forgiven, because we are racing against time...(C1)"

"Thanks to this online system, both the customer representatives and we can track the progressive stages of the process... (P10)" 
The next second-order code, "Services variety", represents the service range offered by customs services providers to fulfil the needs of customers as much as possible. These services are mainly logistics, documentation, accounting, consulting, depot/entrepot, insurance and customer training. Service providers are aware that the variety of services is highly appreciated by customers as they ideally desire one name to contact for all services.

"We provide our customers with customs, logistics, and public accountant services as a package...(P10)"

"It is important that they can provide us with consultancy services...(C10)"

"After the tender, we consider.. services variety regarding transport and warehouse...(C6)"

"We have to organize the documents according to product correctly and send related papers...(P3)"

"I wish they said, 'I'm handling the insurance, you may buy it more expensively, but I can handle it'. This service would be more useful...(C9)"

"I provide customs and transport services for the customers...(P1)"

"Some of the companies we are working with demand training sessions...(P9)"

The third second-order code, "Value perception on customs services", includes additional opportunities accompanying customs services, perceived contribution to the customer's company, perceived importance of services provided and valuable offers made by the service provider when marketing services.

"Therefore, the customer has customized service; they have an indirect profit because we have privileges with warehouses...(P6)"

"In foreign trade, customs brokers are very important service providers for us since they represent the customer company regarding the process with the state; their contribution to the relationship is vital... (C6)"
"Customs brokerage services are the sine qua non regarding foreign trade...(P2)"

"The broker may have deep knowledge and experience but if they do not market themselves with a valuable offer, other firms get ahead of them easily... (C5)"

\subsection{Marketing Criteria Regarding Company, Personnel and Service Dimensions}

Although some of the factors found in this study have been identified similarly to some extent by previous studies on services marketing logistics in particular (e.g. quality of contact personnel, accuracy of order, timeliness, quality of information in LSQ and tangibles, reliability, empathy in SERVQUAL) [22], this study provides insight exclusively for customs services from a different perspective since it was not discussed under another supply chain channel but was focused on specifically.

The dimensions associated with certain first-order codes were generated specifically for the customs environment by taking into account the reviews from both parties engaging in the service process. The results have similarities with Parasuraman's [23] multiple-item scale for measuring consumer perceptions on services and Mentzer's [15] logistics service quality scale. However, in this study, previously discovered items were put into different, more inclusive categories as company, personnel and service capability, which may have only been touched on previously within the capabilities literature. This study synthesizes those items with new ones as well as grouping them distinctively for customs services from a broad perspective by comparing service providers' key marketing items with customer companies' service expectations and perceptions.

The content analysis showed there is a gap in the marketing criteria when each side is handled separately. As Figure 1 shows, customer companies' expectations of the 


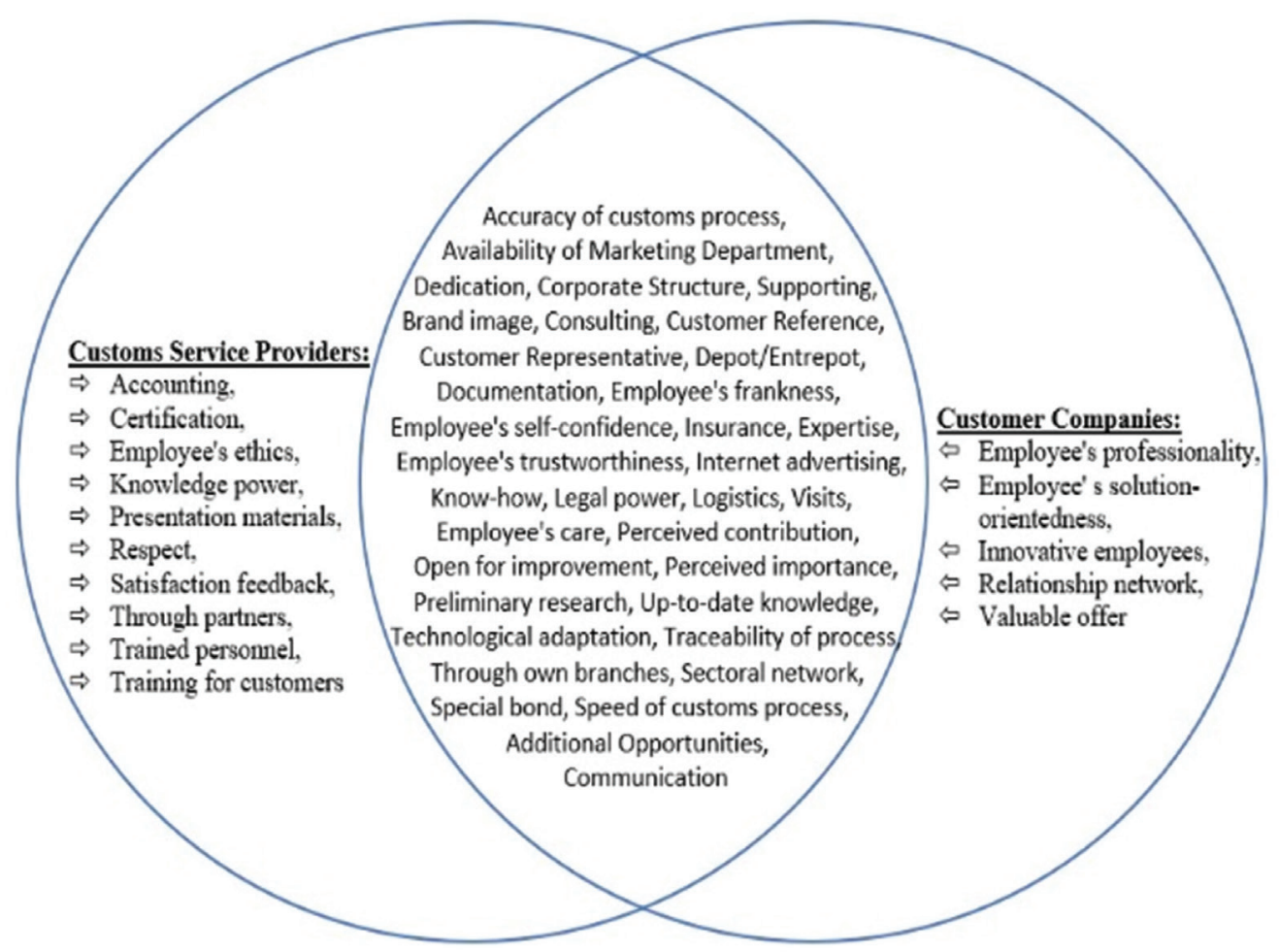

Figure 1. Comparison of Marketing Criteria by Service Providers and Customer Companies

professionalism, solution orientation, and innovativeness of the provider company's employees, along with the relation network of the provider company and valuable offers accompanying the services provided were omitted from service providers' marketing criteria. Turning to the service providers, customer companies do not particularly emphasize accounting services as a package service, nor their certification and knowledge power, employee ethics, respect gained, trained personnel or services provided through partners. Rather, they take them for granted as presentation marketing materials since they consider them as trivial, along with the training offered by service provider companies for customers' employees as service providers do.

\section{Conclusion}

This study identified customs services marketing criteria by focusing on customers' expectations and perceptions, and service providers' existing capabilities within the B2B environment in Izmir, Turkey, since emerging markets play a significant role in the world economy regarding foreign trade. The qualitative investigation in this study enabled new B2B marketing criteria to be developed by taking into consideration the existing literature on B2B services marketing. The results indicate that the customs services marketing criteria taken into consideration by customers for service provider choice may be different from those for other services within the B2B environment.

Determining marketing criteria for customs services is critical to marketing performance, and has prominent theoretical and managerial implications. This is the first study to identify marketing criteria dyadically for customs services in an important developing market, Turkey, İzmir, in a B2B environment. This study 
therefore makes a valuable contribution to the literature and can encourage researchers and market practitioners to study customs services marketing in other economies.

Even though services marketing, service quality and service perceptions are common topics in the literature, customs services marketing has not drawn much exclusive attention. This study has, therefore, added to the academic literature by discovering three dimensions of marketing criteria. Moreover, this study is the first to analyze marketing criteria dyadically by taking into consideration the existing capabilities of service providers and customer companies' service expectations and perceptions within the B2B environment.

This study has managerial implications that could be highly beneficial for marketers in the customs services industry. Although the importance of marketing in B2B markets has been noted by previous researchers, B2B managers are still not aware which key criteria should be promoted and are considered vital by customer companies. Even though marketing has been recognized as a valuable means to highlight what services providers can offer for customer companies, a specific focus is required for each service segment for best implementation and customer satisfaction.

With the help of the marketing criteria dimensions found in this study, marketers can draw up a strategic marketing plan exclusively for customs services industry. It may also help recognize regional or national cultural differences, which would enable an appropriate country-specific marketing plan to be formulated. Service providers can highlight their capabilities as well as taking into consideration the criteria used by customer companies for satisfying existing customers, attracting new customers and expanding their market share in today's competitive environment. Marketers can focus on their distinct competences company-wide, including the personnel and service individually, and position themselves within the industry with greater recognition and reputation.

\subsection{Limitations and Future Research}

This study has certain limitations that can also encourage further research. This study's sample includes companies in Turkey, as one of the most significant emerging economies in terms of foreign trade. Further research can focus on other economies, either developing or developed.

The sample can also be deepened by moving the research area overseas for comparing marketing criteria differences within the customs services industry due to its global nature. This may reveal further cultural and economic factors affecting marketing criteria considered by customs services marketers and customer companies in different contexts.

Another point for further studies to consider is the sample companies' scale. Researchers may concentrate on comparing small, medium and large-scale companies' marketing criteria since their structure, competence and target customer portfolio may vary according to scale.

\section{References}

[1] Baluch, I. (2006). The changing role of the freight forwarder. EC/AGM.

[2] Özgen, A., \& Tanyas, M. (2011). Joint selection of customs broker agencies and international road transportation firms by a fuzzy analytic network process approach. Expert Systems with Applications, 38(7), 8251-8258.

[3] Fedorenko, R. V., Sosunova, L. A., \& Khramtzova, E. (2015). About the Organization of the Customs Service at the Mesolevel.

[4] Gulc, A. (2017). Models and methods of measuring the quality of logistic service. Procedia Engineering, 182, 255-264. 
[5] Boksberger, P. E., \& Melsen, L. (2011). Perceived value: a critical examination of definitions, concepts and measures for the service industry. Journal of Services Marketing, 25(3), 229-240.

[6] Spohrer, J., Maglio, P. P., Bailey, J., \& Gruhl, D. (2007). Steps toward a science of service systems. Computer, $40(1)$.

[7] Wladawsky-Berger, I. (2006). 'PeopleOriented, Services-Intensive, MarketFacing Complex Systems.

[8] Vargo, S. L., \& Akaka, M. A. (2009). Service-dominant logic as a foundation for service science: clarifications. Service Science, 1(1), 32-41.

[9] Kuzgun, E., \& Asugman, G. (2015). Value in services-A service dominant logic perspective. Procedia-Social and Behavioral Sciences, 207, 242-251.

[10] Gray, B. J., Matear, S., Deans, K. R., \& Garrett, T. (2007). Assessing sources of competitive advantage in a servicedominant world. Australasian Marketing Journal (AMJ), 15(1), 6975.

[11] Mudie, P., \& Cottam, A. (2010). Management and marketing of services. Routledge.

[12] Parasuraman, A., Zeithaml, V. A., \& Berry, L. L. (1985). A conceptual model of service quality and its implications for future research. the Journal of Marketing, 41-50.

[13] Sasser, W. E., Olsen, R. P., \& Wyckoff, D. D. (1978). Management of service operations: Text, cases, and readings. Allyn \& Bacon.

[14] Grönroos, C. (1982). Strategic management and marketing in the service industry, publications of the Swedish school of economics and business administration.

[15] Mentzer, J. T., Flint, D. J., \& Kent, J. L. (1999). Developing a logistics service quality scale. Journal of Business Logistics, 20(1), 9.
[16] Lehtinen, U., \& Lehtinen, J. R. (1982). Service quality: a study of quality dimensions. Service Management Institute.

[17] Uyguç, N. (1998). Hizmet sektöründe kalite yönetimi; stratejik bir yaklaşım. Dokuz Eylül Yayınları, 1, 37-38.

[18] Gilmore, A., \& Carson, D. (1996). "Integrative" qualitative methods in a services context. Marketing Intelligence \& Planning, 14(6), 21-26.

[19] Denzin, N. K., \& Lincoln, Y. S. (Eds.). (2011). The Sage handbook of qualitative research. Sage.

[20] DiCicco-Bloom, B., \& Crabtree, B. F. (2006). The qualitative research interview. Medical education, 40(4), 314-321.

[21] Whiting, L. S. (2008). Semi-structured interviews: guidance for novice researchers. Nursing Standard, 22(23), 35-40.

[22] Rahmat, A. K., \& Faisol, N. (2016). Manufacturers Satisfaction on Logistics Service Quality: Operational, Relational and National Culture. Procedia-Social and Behavioral Sciences, 224, 339-346.

[23] Parasuraman, A., Zeithaml, V. A., \& Berry, L. L. (1988). Servqual: A multiple-item scale for measuring consumer perc. Journal of retailing, 64(1), 12. 